\title{
Pengaruh Pemberian Ekstrak Kayu Manis terhadap Gambaran Histopatologi Ginjal pada Tikus Putih Jantan yang Diinduksi Parasetamol
}

\author{
Rachma Eka Rani ${ }^{1}$, Eva Pravitasari Nefertiti ${ }^{2}$, Fitri Handajani ${ }^{3 *}$ \\ Fakultas Kedokteran Universitas Hang Tuah ${ }^{1,2,3}$ \\ *e-mail: fitrihandajanidr@gmail.com
}

\begin{abstract}
Abstrak
Kayu manis (Cinnamomun burmannii) mengandung flavonoid dan sinamaldehid yang berguna sebagai antioksidan dan bersifat renal protektor. Parasetamol berguna sebagai antipiretik dan analgesik. Parasetamol dimetabolisme oleh sitokrom $\mathrm{P}_{450}$ di sel hepar membentuk glukoronida, sulfat, dan NAPQI. NAPQI merupakan hasil metabolit yang sangat reaktif dan mengakibatkan stres oksidatif. Penelitian ini bertujuan untuk mengetahui efek pemberian ekstrak kayu manis yang dapat mencegah kerusakan sel tubulus ginjal tikus putih jantan yang diinduksi parasetamol. Penelitian ini menggunakan metode post test only control group design Tiga Puluh ekor tikus yang dibagi menjadi 3 kelompok; (1) kelompok kontrol negatif tanpa perlakuan, (2) kelompok kontrol positif yang diinduksi parasetamol dosis tunggal $1750 \mathrm{mg} / \mathrm{kgBB}$ pada hari ke 14, (3) kelompok perlakuan yang diberi ekstrak kayu manis dosis $400 \mathrm{mg} / \mathrm{kgBB}$ selama 14 hari lalu diinduksi parasetamol dosis tunggal $1750 \mathrm{mg} / \mathrm{kgBB}$ pada hari ke 14. Pada hari ke 17 hewan coba dikorbankan, dilakukan pengambilan ginjal dan dipemeriksa secara mikroskopik. Selanjutnya dilakukan uji Kruskal-Wallis dan uji Mann-Whitney U. Uji Kruskal-Wallis menunjukkan terdapat perbedaan derajat kerusakan ginjal yang signifikan. Uji Mann-Whitney $U$ menunjukkan perbedaan yang bermakna antara kelompok kontrol negatif dan kelompok kontrol positif $p=0,001(p<\alpha)$; kelompok kontrol negatif dan kelompok perlakuan $p=0,001(p<\alpha)$; juga antara kelompok kontrol positif dan kelompok perlakuan $p=0,001(p<\alpha)$. Terdapat pengaruh pemberian ekstrak kayu manis gambaran histopatologi ginjal tikus putih jantan yang diinduksi parasetamol.
\end{abstract}

Kata Kunci: Ekstrak kayu manis (Cinnamomum burmannii), parasetamol, gambaran histopatologi ginjal

\section{Effect of Giving Cinnamon Extract on Kidney Histopathology in Male White Rats Induced by Paracetamol}

\begin{abstract}
Cinnamon (Cinnamomum burmannii) contains flavonoids and cinnamaldehyde which are useful as antioxidants and renal protectors. Paracetamol is useful as an antipyretic and analgesic. Paracetamol is metabolized by cytochrome P450 in liver cells to form glucuronide, sulfate, and NAPQI. NAPQI is the result of highly reactive metabolites and cause oxidative stress. This study aim to know the effect of cinnamon extract which can prevent damage of renal tubular cell rats male induced by paracetamol. the method in this study using the post test only control group design method. 30 rats used and divided into 3 groups (1) untreated group, (2) rats which were induced by single dose paracetamol $1750 \mathrm{mg} / \mathrm{kgBW}$ on 14th day, and (3) rats were which given cinnamon extract dose $400 \mathrm{mg} / \mathrm{kgBW}$ for 14 days then induced single dose paracetamol 1750 $\mathrm{mg} / \mathrm{kgBW}$ on day 14th. On the 17th day the kidneys are taken and microscopic examination is performed. Data analysis uses the Kruskal-Wallis test and the Mann-Whitney U test. The Kruskal-
\end{abstract}


Pengaruh Pemberian Ekstrak Kayu Manis terhadap Gambaran Histopatologi Ginjal pada Tikus.. Rachma Eka Rani, Eva Pravitasari Nefertiti, Fitri Handajani

Wallis test showed a significant difference in the degree of kidney damage. The Mann-Whitney $U$ test showed a significant difference between the negative control group and the positive control group $p=0.001$; negative control group and the treatment group $p=0.001$; also between the positive control group and the treatment group $p=0.001$ There is an effect of administration of cinnamon extract on the histopathological picture of the kidney of white rats male induced by paracetamol.

Keyword: Cinnamon extract (Cinnamomum burmannii), paracetamol, renal histopathology.

\section{PENDAHULUAN}

Kayu manis (Cinnamomum burmannii) merupakan penghasil kulit kayu untuk bahan baku rempah. Hasil sampingan pada saat panen berupa batang, daun dan ranting dapat dimanfaatkan menjadi beragam produk bernilai ekonomis. Kayu manis merupakan komoditas unggulan, terutama di daerah Sumatera Barat dan Kabupaten Kerinci, sebagai daerah sentra produksi kayu manis Indonesia. Batang kayu manis dapat dimanfaatkan sebagai bahan baku particle board, sedangkan daun dan rantingnya dapat disuling untuk mendapatkan minyak yang dapat digunakan sebagai bahan pestisida nabati (Ferry, 2013).

Kayu manis merupakan salah satu tanaman yang mudah didapat dan murah. Hasil utama kayu manis adalah kulit batang dan dahan, sedangkan hasil sampingan adalah ranting dan daun (Tasia, 2014). Kayu manis dapat diolah menjadi bermacammacam produk seperti dalam bentuk bubuk, minyak atsiri atau oleoresin. Kayu manis berbau wangi dan berasa manis sehingga dapat dijadikan bahan pembuat sirup dan rasa pedas sebagai penghangat tubuh. Kulit kayu manis dalam bentuk asli seperti potongan atau bubuk digunakan untuk bermacam-macam bumbu masakan daging dan ikan, dan sebagai campuran dalam minuman (teh, kopi, dan kakao). Kulit kering kayu manis yang direndam dalam air teh dan diminum dapat menurunkan kadar kolesterol tubuh dan mengencerkan darah sehingga baik untuk penderita stroke. Minyak atsiri atau oleoresin dari kayu manis mengandung beberapa senyawa kimia seperti cinnamaldehyde, eugenol, methyl ketene, furfural, benzaldehyde, nonyl aldehyde, hydrocinnamic aldehyde, cuminaldehyde, dan coumarin. Kandungan tersebut diketahui berguna untuk antioksidan, anti inflamasi, anti proliferatif, dan menurunkan aktivitas radikal bebas. Karena kandungan sinamaldehid dan flavonoid pada kayu manis yang berguna sebagai antioksidan dan menurunkan kandungan radikal bebas dapat dianggap bahwa kayu manis memiliki sifat renal protektor (Ferry, 2013). 
ISSN 1978-2071 (Print); ISSN 2580-5967 (Online) Jurnal IImiah Kedokteran Wijaya Kusuma 10(2) : 142-153, September 2021

Ginjal adalah organ yang memegang peran utama mempertahankan homeostasis dengan mengatur konsentrasi berbagai konstituen plasma khususnya elektrolit dan air, serta dengan menghilangkan semua sisa metabolisme (Godoy-Santos, Rammelt dan Zoboli, 2017). Plasma melewati ginjal berulang kali untuk pempertahankan konstituen plasma yang berguna bagi tubuh dan menghilangkan bahan sisa yang tidak dibutuhkan dalam urin. Pada saat yang bersamaaan ginjal juga mengatur volume dan osmolaritas darah dengan mengendalikan keseimbangan garam dan air, juga mengatur $\mathrm{pH}$ dengan mengembalikan asam dan basa urin (Kumar, 2012).

Parasetamol merupakan obat yang sering digunakan sebagai antipiretik dan analgesik. Dalam keadaan normal, parasetamol terkonjugasi di hati untuk membentuk glukoronida inaktif atau metabolit sulfat dan sebagian lagi terhidroksilasi membentuk $\mathrm{N}$-acetyl benzoiminoquinone

(N-acetyl-pbenzoquinoneimine atau NAPQI), suatu metabolit yang sangat reaktif, NAPQI bereaksi dengan glutathione dan menjadikan NAPQI inaktif. NAPQI selanjutnya akan diekskresi melalui ginjal. Dalam dosis parasetamol yang berlebihan glutathione habis, dan terjadi peningkatan cepat konsentrasi NAPQI menyebabkan nekrosis. Induksi parasetamol yang signifikan hepatotoksisitas biasanya memicu nefrotoksisitas. Insufisiensi ginjal dilaporkan terjadi pada 1-2\% dari pasien yang terpapar toksisitas parasetamol. Hal ini tejadi karena pada proses inflamasi akan terjadi fagositosis dan penghancuran mikroorganisme. Keadaan ini merangsang neutrofil, eosinfil, monosit, dan makrofag untuk mensintesis dan melepaskan beberapa reactive oxygen spesies (ROS). ROS diproduksi saat metabolisme normal dan mungkin dapat meningkat secara drastis saat terjadi inflamasi, maka sel-sel dan jaringan dalam tubuh mengembangkan sistem pertahanan berupa antioksidan enzimatik dan non-enzimatik untuk mengurangi agen pengoksidasi. Aktivitas radikal bebas dapat dihambat oleh sistem antioksidan yang melengkapi sistem kekebalan. Ketidakseimbangan antioksidan dan oksidan yang dihasilkan dari produksi ROS yang berlebihan disebut stress oksidatif. NAPQI akan mengikat sel makromolekul dan tetap dalam bentuk yang sangat reaktif sehingga akan mengakibatkan stres oksidatif sehingga terjadi kerusakan oksidatif hingga terjadi kematian sel (nekrosis) (Brunton, 2008, Canayakin et al., 2016).

$$
\text { Penggunaan kayu manis dapat }
$$
berguna untuk mengurangi nekrosis dengan mengurangi agen stres oksidatif. Saat 
Pengaruh Pemberian Ekstrak Kayu Manis terhadap Gambaran Histopatologi Ginjal pada Tikus.. Rachma Eka Rani, Eva Pravitasari Nefertiti, Fitri Handajani

parasetamol dikomsumsi berlebihan, jalur metabolisme parasetamol yang dibantu enzim sitokrom P450 akan semakin banyak sehingga jumlah NAPQI juga meningkat. Karena pada keadaan umum NAPQI meruoakan zat yang sangat reaktif dan harus diikat glutathione agar menjadi inaktif, tapi pada keadaan NAPQI berlebih, glutathione tidak dapat memenuhi kebutuhan NAPQI sehingga NAPQI akan mengikat sel makromolekul tapi tetap dalam keadaan sangat reaktif. Ikatan NAPQI dalam sel akan mengakibatkan radikal bebas (ROS dan RNS) meningkat. Saat didalam sel ROS dan RNS meningkat sehingga mengganggu kerja mitokondria untuk menghasilkan ATP akibatnya sel tidak dapat melakukan metabolismenya dan bila terjadi dalam waktu yang lama akan mengalami kematian (nekrosis). Kayu manis mengandung sinamaldehid dan flavonoid yang memiliki gugus hidroksil dan ikatan rangkap yang memiliki sifat donor elektron. Saat berhadapan dengan ROS, sinamaldehid dan flavonoid akan melepaskan atom hidrogen untuk menghentikan reaksi oksidasi sehingga ROS akan bersifat netral dan berhenti bersifat radikal (Abdeen et al., 2019).

Pada penelitian ini peneliti ingin mengetahui efek pemberian ekstrak kayu manis pada kerusakan sel tubulus ginjal tikus putih jantan yang diinduksi parasetamol.

\section{METODE PENELITIAN}

Penelitian ini menggunakan post test only control group design. Hewan coba yang digunakan 30 ekor rattus norvegicus jantan dibagi menjadi 3 kelompok yaitu kelompok kontrol (-) adalah kelompok hewan coba tanpa perlakuan, kelompok kontrol (+) adalah kelompok hewan coba yang diinduksi parasetamol dengan dosis tunggal $1750 \mathrm{mg} / \mathrm{KgBB}$ pada hari ke 14 dan kelompok $\mathrm{P}$ adalah kelompok hewan coba yang diberi ekstrak kayu manis dosis 400 $\mathrm{mg} / \mathrm{KgBB}$ selama 13 hari kemudian diberi ekstrak kayu manis dosis $400 \mathrm{mg} / \mathrm{KgBB}$ dan diinduksi parasetamol dosis tunggal 1750 $\mathrm{mg} / \mathrm{KgBB}$ pada hari ke 14. Dosis ini dipilih karena merupakan dosis optimal yang dapat menimbulkan kerusakan ginjal (Sugiharto, 2018). Pada hari ke 17 hewan coba dikorbankan dan pada ketiga kelompok tikus tersebut dilakukan pengamatan gambaran histopatologi sel tubulus ginjal.

Pemeliharaan dan terminasi hewan model dilakukan di Kandang Hewan Coba Fakultas Kedokteran Hewan Universitas Airlangga. Pengamatan gambaran histopatologi ginjal tikus di laboratorium Patologi Anatomi Fakultas Kedokteran Universitas Hang Tuah Surabaya. 


\section{Alat dan Bahan}

Alat pada penelitian ini menggunakan oven, alat penggiling, blender, evaporator, gelas beker, mikroskop cahaya. Adapun bahanbahan yang digunakan pada penelitian ini adalah kayu manis, etanol $96 \%$, tablet parasetamol, CMC-Na, jaringan ginjal, larutan buffer formalin 10\%, paraffin, alcohol 70\%, xylol, hematoxyn-Eocin (HE)

\section{Pembuatan Ekstrak Kayu Manis}

Sebanyak 2 kg Kayu manis dicuci kemudian diangin-anginkan hingga setengah kering. Kemudian dimasukkan ke oven dengan suhu 50들 sampai kering. Setelah kering, dihaluskan dengan alat penggiling yang dilanjutkan blender. Serbuk kemudian dimaserasi (direndam dengan etanol 96\% selama 24 jam), disaring, difiltrat, diambil dilakukan berulang hingga mendapatkan filtrat yang jernih. Filtrat jernih diuapkan dengan alat rotary evaporator hingga kental. Ekstrak yang diperoleh disimpan sementara dalam lemari es selama eksperimen berlangsung.

\section{Pembuatan Suspensi Parasetamol}

Dalam penelitian ini digunakan tablet parasetamol dari pabrik kimia farma, dosis parasetamol yang diberikan sebesar 1750 $\mathrm{mg} / \mathrm{kgBB}$. Jika berat badan tikus yang digunakan adalah 150-200 gram. Hasil konversi dosis parasetamol pada manusia dengan berat badan $70 \mathrm{~kg}$ ke tikus dengan berat badan $200 \mathrm{mg}$ adalah 0,018. Jika dosis yang diberikan pada tikus adalah 1750 $\mathrm{mg} / \mathrm{kgBB}$ dosis manusia.

Dosis untuk tikus adalah $=1750 \mathrm{mg} / \mathrm{kgBB} \mathrm{x}$ 0,018 setara dengan $31,5 \mathrm{mg} / \mathrm{kgBB}$ atau setara dengan $350 \mathrm{mg} /$ 200gram

Parasetamol bersifatnya yang tidak larut dalam air, kemudian parasetamol 350 mg dalam bentuk serbuk kemudian disuspensikan dengan CMC-Na 1\% yakni 1 gram CMC-Na dicampur dengan 100ml aquades. Setiap perlakuan memerlukan 50 $\mathrm{ml}$ dosis parasetamol, sehingga CMC-Na yang diperlukan tiap $350 \mathrm{mg}$ parasetamol adalah sebanyak $0,01 \mathrm{gr} / \mathrm{ml} \times 50 \mathrm{ml}=0,5 \mathrm{gr}$.

Parasetamol diaduk hingga larut sempurna bersama serbuk parasetamol yang di tambahkan dengan aquades sampai $50 \mathrm{ml}$. Volume maksimum dosis yang diberikan pada tikus secara normal adalah 5 $\mathrm{ml}$, sehingga suspensi parasetamol sebanyak $50 \mathrm{ml}$ dibagi dengan banyaknya tikus yang mendapat perlakuan yakni 10 tikus kelompok kontrol positif dan 10 tikus kelompok perlakuan sehingga setiap tikus mendapatkan 2,5 ml larutan parasetamol.

\section{Cara Pembuatan Histopatologi Ginjal dan}

\section{Pengamatan Histopatologi Ginjal}

Diambil sampel jaringan (ginjal), kemudian dilakukan fiksasi menggunakan larutan buffered neutral formalin $10 \%$. Setelah itu dilakukan pemotongan jaringan menggunakan scalpel dengan ketebalan 0,3-0,5 $\mathrm{mm}$ dan disusun dalam tissue 
Pengaruh Pemberian Ekstrak Kayu Manis terhadap Gambaran Histopatologi Ginjal pada Tikus.. Rachma Eka Rani, Eva Pravitasari Nefertiti, Fitri Handajani

cassette. Selanjutnya dilakukan dehidrasi dengan alkohol $70 \%$ selama 2 jam untuk mengeluarkan cairan yang terdapat dalam jaringan yang telah difiksasi. Lalu dengan menggunakan xylol dilakukan pejernihan. Setelah itu dimasukkan ke dalam mesin vakum yang diberi paraffin cair. Metode ini disebut dengan impregnasi yaitu proses untuk mengeluarkan cairan jaringan diganti dengan paraffin. Selanjutnya melakukan embedding/block paraffin atau proses pembuatan blok preparat agar mudah dipotong dengan rotary microtom dengan ketebalan 3-4 $\mathrm{nm}$. Selanjutnya melakukan penjernihan dan dehidrasi dengan menggunakan xylol dan alkohol. Setelah itu melakukan pewarnaan dengan Hematoxyin-Eosin (HE).

Pengamatan histopatologi ginjal dilakukan dibawah mikroskop cahaya dengan perbesaran 400x. Pengamatan dilakukan pada lapangan pandang 1 , lapangan pandang 2, lapangan pandang 3, lapangan pandang 4, lapangan pandang 5 pada sediaan ginjal. Kemudian dilakukan perhitungan sel tubulus ginjal yang mengalami nekrosis. Dilakukan grading berdasarkan derajat kerusakan sel tubulus ginjal tikus putih jantan sesuai tabel 1

Tabel 1. Grade Kerusakan Ginjal

\begin{tabular}{ll}
\hline Grade & Kerusakan \\
\hline 0 & Tidak ada kelainan \\
1 & Nekrosis mengenai $1 \%-25 \%$ tubulus ginjal pada bagian korteks per lapangan pandang \\
2 & Nekrosis mengenai $26 \%-50 \%$ tubulus ginjal pada bagian korteks per lapangan pandang \\
3 & Nekrosis mengenai $51 \%-75 \%$ tubulus ginjal pada bagian korteks per lapangan pandang \\
4 & Nekrosis mengenai $76 \%-100 \%$ tubulus ginjal pada bagian korteks per lapangan pandang \\
\hline
\end{tabular}

Analisis data menggunakan SPSS

(Statistical Product an Service Solution) 23.0 menggunakan uji Kruskall-Wallis untuk mengetahui ada tidaknya kerusakan hepar diantara kelompok sampel penelitian.

\section{HASIL}

Dari data hasil penelitian ini didapatkan hasil pengamatan kerusakan ginjal hewan coba seperti pada tabel 2.

Derajat kemaknaan yang digunakan adalah $\alpha=0,05$.

Tabel 2 data Kerusakan Ginjal pada tiap kelompok

\begin{tabular}{|c|c|c|c|}
\hline \multicolumn{2}{|c|}{ Kelompok } & \multirow{2}{*}{$\begin{array}{l}\% \text { kerusakan ginjal (\%) } \\
23,46\end{array}$} & \multirow{2}{*}{$\begin{array}{l}\text { grade kerusakan ginjal } \\
1\end{array}$} \\
\hline$K(-)$ & 1 & & \\
\hline & 2 & 21,86 & 1 \\
\hline & 3 & 22,45 & 1 \\
\hline & 4 & 20,13 & 1 \\
\hline & 5 & 24,00 & 1 \\
\hline & 6 & 21,80 & 1 \\
\hline
\end{tabular}


ISSN 1978-2071 (Print); ISSN 2580-5967 (Online) Jurnal IImiah Kedokteran Wijaya Kusuma 10(2) : 142-153, September 2021

\begin{tabular}{cccc} 
& 7 & 22,79 & 1 \\
& 8 & 20,11 & 1 \\
\hline$K(+) \quad 1$ & 82.19 & 4 \\
& 2 & 85,01 & 4 \\
& 3 & 87,70 & 4 \\
& 4 & 88,47 & 4 \\
& 5 & 86,07 & 4 \\
& 6 & 86,52 & 4 \\
& 7 & 89,50 & 4 \\
& 8 & 89,15 & 4 \\
\hline$P$ & 1 & 63,17 & 3 \\
& 2 & 61,80 & 3 \\
& 3 & 63,00 & 3 \\
& 4 & 60,13 & 3 \\
& 5 & 69,00 & 3 \\
& 6 & 61,86 & 3 \\
& 7 & 62,69 & 3 \\
8 & 60,11 & 3 \\
\hline
\end{tabular}

Gambar 1. Gambaran histopatologi ginjal kelompok percobaan dengan pewarnaan HE pemeriksaan menggunakan mikroskop cahaya dengan pembesaran 400x.

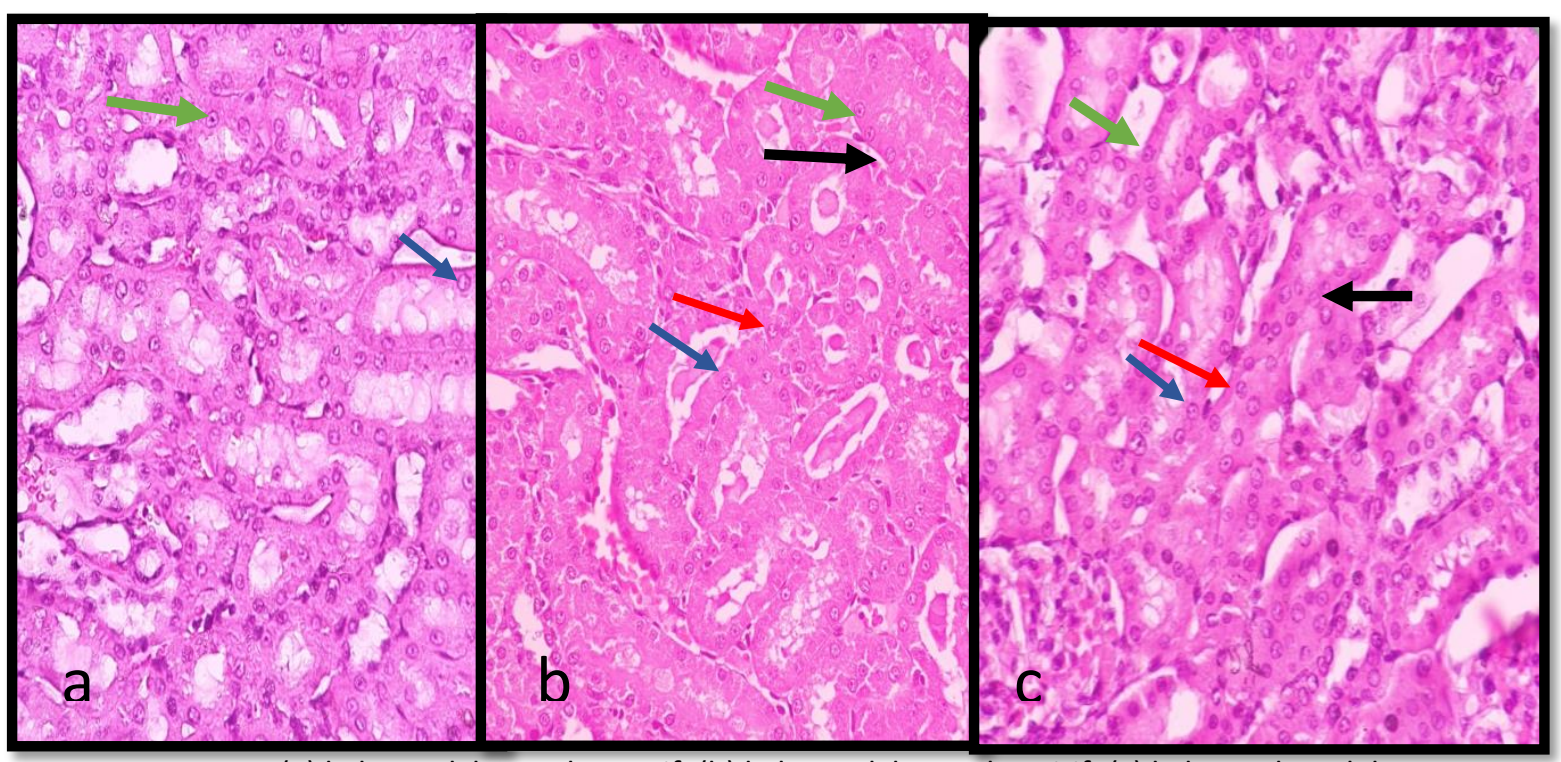

Keterangan: (a) kelompok kontrol negatif, (b) kelompok kontrol positif, (c) kelompok perlakuan

\section{Uji Kruskal-Wallis}

Uji Kruskal-Wallis adalah uji non parametrik yang digunakan untuk membandingkan tiga atau lebih kelompok data sampel dengan variabel terikat yang berskala ordinal berdasarkan pengukuran yang dilakukan satu kali pada sampel. Pada penelitian ini, didapatkan hasil uji Kruskal-Wallis dengan $\mathrm{p}=0,001$ pada kelompok kontrol negatif dengan kelompok kontrol positif, $p=0.001$ pada kelompok kontrol positif dan kelompok perlakuan. Hal ini menunjukkan bahwa terdapat perbedaan yang bermakna pemberian ekstrak kayu manis pada penghambatan kerusakn ginjal akibat induksi parasetamol. 
Pengaruh Pemberian Ekstrak Kayu Manis terhadap Gambaran Histopatologi Ginjal pada Tikus.. Rachma Eka Rani, Eva Pravitasari Nefertiti, Fitri Handajani

\section{PEMBAHASAN}

Data hasil pengamatan secara histopatologi, dilakukan uji statistic menggunakan uji non parametrik, yaitu uji Kruskal-Wallis. Hasil uji Kruskal-Wallis menunjukkan adanya perbedaan bermakna kerusakan sel ginjal yang dinilai melalui gambaran histopatologi antara 3 kelompok hewan coba dalam penelitian ini. Untuk mengetahui signifikansi antar kelompok, digunakan uji Mann-Whitney $U$ untuk membandingkan nilai signifikansi pada setiap 2 kelompok yang diteliti.

Hasil uji Mann-Whitney U terhadap kelompok kontrol negatif atau kelompok tanpa perlakuan dengan kelompok kontrol positif atau kelompok yang diberi induksi parasetamol dosis tunggal $1750 \mathrm{mg} / \mathrm{kgBB}$ pada hari ke 14 didapatkan nilai $\mathrm{p}$ yaitu $0,001(p<0,05)$. Hal ini menunjukkan bahwa terdapat perbedaan yang bermakna kerusakan sel ginjal antara 2 kelompok tersebut. Dimana pada kelompok kontrol negatif seluruhnya memiliki skor kerusakan 1 , yang berarti terdapat nekrosis pada $1 \%$ $25 \%$ tubulus ginjal bagian korteks per lapangan pandang. Sementara pada kelompok kontrol positif didapatkan skor 4 pada keseluruhan, yang berarti terdpat nekrosis pada $76 \%$ - 100\% tubulus ginjal pada bagian korteks per lapangan pandang.

Untuk menginduksi kerusakan tubulus ginjal digunakan parasetamol dosis tunggal $1750 \mathrm{mg} / \mathrm{kgBB}$. Dosis ini termasuk dosis tinggi sehingga dapat menyebabkan kerusakan sel epitel tubulus ginjal. Induksi parasetamol dosis tinggi digunakan sebagai model terjadinya nekrosis sel epitel tubulus ginjal. Parasetamol akan akan dioksidasi melalui sitokrom P450 dan menghasilkan NAPQI yang menyebabkan kerusakan dari tubulus ginjal (Mitić-Zlatković et al., 1998). NAPQI akan bereaksi dengan gugus nukleofilik pada protein, DNA dan mitokondria serta menimbulkan stres oksidatif sehingga dapat menyebabkan kematian sel. Nekrosis terjadi setelah suplai darah hilang atau setelah terpapar toksin dan ditandai dengan dengan pembengkakan sel, denaturasi protein, serta kerusakan organel sel (Katzung dan Trevor, 2015).

Konsentrasi parasetamol tinggi dapat menyebabkan kerusakan sel hepatosit dan sel ginjal, karena pada proses inflamasi akan terjadi fagositosis dan penghancuran mikroorganisme. Keadaan ini merangsang neutrofil, eosinfil, monosit, dan makrofag untuk mensintesis dan melepaskan beberapa reactive oxygen spesies (ROS). ROS diproduksi saat metabolisme normal dan mungkin dapat meningkat secara drastis saat terjadi inflamasi, maka sel-sel dan jaringan dalam tubuh mengembangkan sistem pertahanan berupa antioksidan enzimatik dan non-enzimatik untuk 
ISSN 1978-2071 (Print); ISSN 2580-5967 (Online) Jurnal IImiah Kedokteran Wijaya Kusuma 10(2) : 142-153, September 2021

mengurangi agen pengoksidasi. Aktivitas radikal bebas dapat dihambat oleh sistem antioksidan yang melengkapi sistem kekebalan. Ketidakseimbangan antioksidan dan oksidan yang dihasilkan dari produksi ROS yang berlebihan disebut stress oksidatif. NAPQI akan mengikat sel makromolekul dan tetap dalam bentuk yang sangat reaktif sehingga akan mengakibatkan stres oksidatif sehingga terjadi kerusakan oksidatif hingga terjadi kematian sel (nekrosis) (Handajani, 2019; Radak et al., 2008; Naggayi et al., 2015 )

Dalam proses pemberian parasetamol pada jalur metabolisme utama melalui sitokrom P450 membentuk senyawa antara yaitu NAPQI yang bersifat reaktif. Pada keadaan normal, senyawa antara ini dieliminasi melalui konjugasi dengan glutahion dalam ginjal menjadi sangat rendah akibat mengkompensasi NAPQI. Berkurangnya glutation ini mengakibatkan kecenderungan sel-sel ginjal yang rentan terhadap cedera oleh oksidan dan menyebabkan NAPQI berikatan secara kovalen pada makromolekul sel yang menyebabkan kerusakan dan kematian sel. Ekstrak kayu manis mengandung zat seperti glutation, dimana glutation berguna mendetoksifikasi atau mengikat NAPQI sehingga NAPQI yang berikatan dengan protein makromolekul akan berkurang (Brunton, 2008).
Hasil uji Mann-Whitney U terhadap kelompok kontrol positif atau kelompok yang diberi induksi parasetamol dosis tunggal $1750 \mathrm{mg} / \mathrm{kgBB}$ pada hari ke 14 dengan kelompok perlakuan atau kelompok yang diberi ekstrak kayu manis dosis 400 $\mathrm{mg} / \mathrm{kgBB}$ selam 14 hari dan diinduksi parasetamol dosis tunggal $1750 \mathrm{mg} / \mathrm{kgBB}$ pada hari ke 14 didapatkan nilai $p$ yaitu $0,001(p<0,05)$. Hal ini menunjukkan bhwa terdapat perbedaan yang bermakna kerusakan sel ginjal antara 2 kelompok tersebut. Dimana pada kelompok kontrol positif seluruhnya memiliki skor kerusakan 4 , yang berarti terdapat nekrosis pada $76 \%$ - $100 \%$ tubulus ginjal pada bagian korteks per lapangan pandang. Sementara pada kelompok perlakuan didapatkan skor 3 pada keseluruhan, yang berarti terdapat nekrosis pada $51 \%$ - 75\% tubulus ginjal pada bagian korteks per lapangan pandang.

Pada penelitian ini digunakan bahan berupa ekstrak kayu manis. Menurut penelitian terdahulu ekstrak kayu manis mengandung flavonoid dan sinamaldehid. Cara kerja antioksidan flavonoid melalui 2 jalur, jalur pertama melalui efek antioksidan yang akan mengoksidasi radikal bebas dan mencegah peroksidasi lipid. Jalur kedua melalui direct radical scavenging yang menghambat aktivitas xanthine oksidase sehingga bisa menurunkan kerusakan oksidatif (Dahal dan Mulukuri, 2015). 
Pengaruh Pemberian Ekstrak Kayu Manis terhadap Gambaran Histopatologi Ginjal pada Tikus.. Rachma Eka Rani, Eva Pravitasari Nefertiti, Fitri Handajani

Sinamaldehid berperan sebagai antioksidan dengan menghambat aldose reduktase yaitu enzim yang berperan pada jalur poliol, sehingga pembentukan stress oksidatif terhambat (Lee, 2002). Saat ekstrak kayu manis ditambahkan dalam kelompok perlakuan, terjadi peningkatan jumlah antioksidan yang memilki sifat renal protektor. Efek nefropotektor pada penelitian ini mampu untuk menurunkan derajat kerusakan ginjal tidak sebaik kelompok tanpa perlakuan.

Hasil uji Mann-Whitney U terhadap kelompok kontrol negatif atau kelompok tanpa perlakuan dengan kelompok perlakuan atau kelompok yang diberi ekstrak kayu manis dosis $400 \mathrm{mg} / \mathrm{kgBB}$ selam 14 hari dan diinduksi parasetamol dosis tunggal $1750 \mathrm{mg} / \mathrm{kgBB}$ pada hari ke 14 didapatkan nilai $p$ yaitu $0,001(p<0,05)$. Hal ini menunjukkan bahwa terdapat perbedaan yang bermakna kerusakan sel ginjal antara 2 kelompok tersebut. Dimana pada kelompok kontrol negatif seluruhnya memiliki skor kerusakan 1, yang berarti terdapat nekrosis pada $1 \%-25 \%$ tubulus ginjal pada bagian korteks per lapangan pandang. Sementara pada kelompok perlakuan didapatkan skor 3 pada keseluruhan, yang berarti terdapat nekrosis pada $51 \%-75 \%$ tubulus ginjal pada bagian korteks per lapangan pandang.

\section{KESIMPULAN}

Berdasarkan penelitian ini dapat disimpulkan bahwa pemberian ekstrak kayu manis dosis $400 \mathrm{mg} / \mathrm{kgBB}$ mampu mencegah derajat kerusakan ginjal tikus putih jantan yang diinduksi parasetamol dosis tunggal $1750 \mathrm{mg} / \mathrm{kgBB}$ secara bermakna.

\section{DAFTAR PUSTAKA}

Abdeen A, Kader AA, Abdo M, Wareth G, Aboubakr $\mathrm{M}$, et al., 2019.
Protective effect of cinnamon
against acetaminophen-mediated
cellular damage and apoptosis in
renal tissue, Environmental
Science and Pollution Research.
Environmental Science and
Pollution Research, 26(1):240-
249. doi: 10.1007/s11356-018-
$3553-2$. Brunton L.L, 2008. Goodman \& Gilman Manual Farmakologi dan Terapi.

Cook SF, Robert, Zafargandy, 2016. Population Pharmacokinetics of Intravenous Paracetamol (Acetaminophen) in Preterm and Term Neonates: Model Development and External Evaluation, Clinical Pharmacokinetics. Springer International Publishing, 55(1): 107-119. doi: 10.1007/s40262- 
015-0301-3.

Canayakin, Bayira, Baygutalpa, Karaoglanb, Atmacac, et al., Paracetamolinduced nephrotoxicity and oxidative stress in rats: the protectiverole of Nigella sativa. PHARMACEUTICAL BIOLOGY, VOL. 54, NO. 10, 2082-2091

Dirjen POM RI, 2009. Farmakope Indonesia edisi IV, Departemen Kesehatan Republik Indonesia. doi: $10.1590 /$ S1984-

82502011000100002.

Ferry $Y$, 2013. DEVELOPMENT PROSPECTS OF CINNAMON PLANT ( Cinnamomum Burmanii L ) IN INDONESIA," Sirinov, 1(1): 11-20. Godoy-Santos AL, Rammelt S dan Zoboli AC, 2017. Clinical anatomy, Foot and Ankle Sports Orthopaedics. doi: 10.1007/978-3-319-15735-1_1.

Greenstein Gary, 2007. The Merck Index: An Encyclopedia of Chemicals, Drugs, and Biologicals (14th edition), Reference Reviews. Emerald Group Publishing Limited, 21(6): 40. doi: 10.1108/09504120710775534.

Handajani F, 2019. OKSIDAN DAN ANTIOKSIDAN PADA BEBERAPA PENYAKIT DAN PROSES PENUAAN. 1 ed. Diedit oleh Fitri Handajani. Surabaya: Zifatama Jawara. Tersedia pada: https://books.google.co.id/books? $\mathrm{id}=\mathrm{H} 9 \mathrm{j} F D \mathrm{wAAQBAJ}$.

Harvey R A, 2012, Lippincott's Illustrated Reviews: Pharmacology 5th edition.

Katzung BG dan Trevor A J, 2015. T H a R I N DETI.

Kumar, 2012. Robbins Basic Pathology, 9th ed, Elsevier. doi: 10.1007/s13398014-0173-7.2.

Lee HS, 2002. Inhibitory activity of Cinnamomum cassia bark-derived component against rat lens aldose reductase. Journal of Pharmacy and Pharmaceutical Sciences. 5(3): 226-230.

Masturoh, Imas; T, N. A. (2018) metodologi penelitian kesehatan.

Mitić-Zlatković, Stevanovik, Flahofik, 1998. Kidney extopeptidases in gentamicin and mercuric chlorideinduced acute renal failure. Cellular Physiology and Biochemistry, 8(5): 278-284. doi: 10.1159/000016289.

Naggayi, Mukiibi, Ezekiel Iliya, 2015. The protective effects of aqueous extract of Carica papaya seeds in paracetamol induced nephrotoxicity in male wistar rats. African Health Sciences. 15(2): 600-605

Peter KV, 2002. Handbook of herbs and 
Pengaruh Pemberian Ekstrak Kayu Manis terhadap Gambaran Histopatologi Ginjal pada Tikus.. Rachma Eka Rani, Eva Pravitasari Nefertiti, Fitri Handajani

spices. I.

Rodwell VW dan Bender DA, 2015. e tind Illustrated Biochemistry. doi: 10.1021/acs.langmuir.6b03449.

Scott, GB, 1988. Functional Histology - a Text and Colour Atlas, Postgraduate Medical Journal. doi: 10.1136/pgmj.64.747.93.

Sugiharto W, 2018. Hang tuah medical journa. 15: 112-132.

Vangalapati, Satya S, Prakas S, 2012. A review on pharmacological activities and clinical effects of Cinnamon species. Research Journal of Pharmaceutical, Biological and Chemical Sciences, 3(1): 653-663.

Widiyanto, Anandito, 2013. EKSTRAKSI

OLEORESIN KAYU MANIS
(Cinnamomum burmannii):

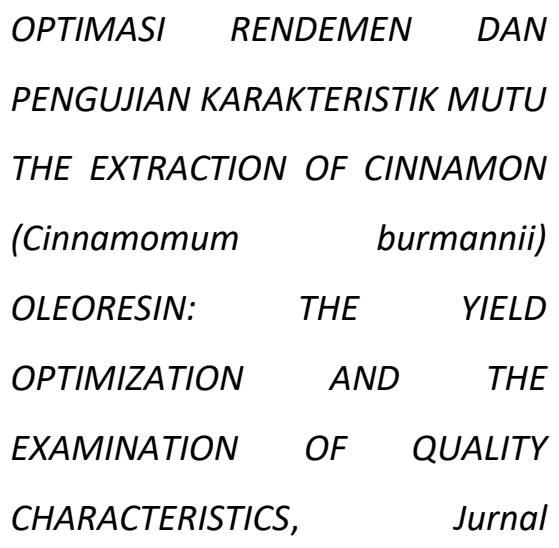

Teknologi Hasil Pertanian.

Yousef MI, Omar, Quendi, 2010. Potential protective effects of quercetin and curcumin on paracetamol-induced histological changes, oxidative stress, impaired liver and kidney functions and haematotoxicity in rat. Food and Chemical Toxicology. Elsevier Ltd, 48(11): 3246-3261. doi: 